\title{
Features of $J$-aggregates formation in pores of nanostructured anodic aluminum oxide
}

\author{
A.V.Sorokin, A.V.Voloshko, I.I.Fylymonova, \\ I.I.Bespalova, S.L.Yefimova
}

\author{
Institute for Scintillation Materials, STC "Institute for Single Crystals", National \\ Academy of Sciences of Ukraine, 60 Lenin Ave., 61001 Kharkiv, Ukraine
}

\section{Received January 15, 2014}

\begin{abstract}
Features of $J$-aggregates formation in highly structured pores of anodic aluminum oxide (AAO) have been studied using steady-state absorption and luminescence spectroscopy and time-resolved luminescence spectroscopy. $J$-aggregates with different structures (spherical and thread-like) were chosen for the studying. Spectroscopic investigations show the presence of both types of the $J$-aggregates in the AAO pores. It leads to a static disorder increasing in the $J$-aggregates. Besides, in the case of the thread-like $J$-aggregates changes in the structure have been supposed also.
\end{abstract}

Исследованы особенности формирования $J$-агрегатов в порах высокоструктурированного анодного оксида алюминия (ААО) с помощью стационарных спектров оптического поглощения и люминесцентной спектроскопии, а также время-разрешенной люминесцентной спектроскопии. Для исследования выбраны $J$-агрегаты с разной структурой (сферической и нитеобразной). Спектроскопические исследования показали наличие $J$-агрегатов обоих типов в порах ААО. Это приводит к увеличению статического беспорядка в $J$-агрегатах. Кроме этого, в случае нитеобразных $J$-агрегатов также предполагается изменение их структуры.

Особливості форлування Ј-агрегатів у порах наноструктурованого анодного оксиду алюмінію. О.В.Сорокін, А.В.Волошко, І.І.Філімонова, І.І.Беспалова, С.Л.Єфілова.

Досліджено особливості формування $J$-агрегатів у порах високо структурованого анодного оксиду алюмінію (AАО) за допомогою стаціонарних спектрів оптичного поглинання та люмінесцентної спектроскопії, а також люмінесцентної спектроскопії з часовим розділенням. Для дослідження обрано $J$-агрегати з різною структурою (сферичною та ниткоподібною). Спектроскопічні дослідження показали наявність $J$-агрегатів обох типів у порах ААО. Це призводить до збільшення статичного безладу в $J$-агрегатах. Крім того, у разі ниткоподібних $J$-агрегатів також передбачається зміна їх структури.

\section{Introduction}

Development of nanomaterials and nanocomposites with defined physical and chemical properties is an important problem of modern material science. Development tendencies of new optical materials for photonics and optoelectronics show that the investigation of organic luminophores properties is very actual nowadays [1-3]. Very perspective objects in this direction are well-ordered molecular nanoclusters called $J$-ag- gregates [4-8]. Interest to solid samples based on $J$-aggregates is primarily related to a perspective of practical application of thin film materials [3]. For example, thin film samples with $J$-aggregates may be used as saturating absorbers of the laser radiation for development of optical memory elements and for devices in nonlinear optics [8-10]. It is connected primarily with the significant increase in stability of $J$-aggregates formed in polymer films [9, 10]. On the other hand, optical properties of organic 
dyes formed in polymer films depend strongly on the polymer properties [3,1012]. To resolve this problem nanoporous materials often used as substrates [13]. One of them is highly porous anodic aluminium oxide (AAO) which demonstrates strict ordering of pores at large surface areas, narrow dispersion of pore diameters and the intervals between them, perfect cylindrical shape and the strictly parallel channels [1418]. Due to it's features AAO is a very attractable for different applications such as sensors and so on [14-18].

Despite intriguing properties of hybrid $J$-aggregates-AAO composites could be expected there are only few studies in this field were found [1, 19, 20]. Authors of [19] used AAO templates to create a matrix of $\mathrm{Au}$ nanorods which were surrounded by J-aggregates shell to examine exciton-plasmon interaction. In [20] AAO pores were used as templates to form cylindrical J-aggregates with controlled shape and sizes.

So, a purpose of present article was to form in AAO pores $J$-aggregates of two different cyanine dyes and to found changing $J$-aggregate spectral properties as a result of the formation into pores. The AAO samples possess an ordered porous structure with a perpendicular arrangement of pore channels relative to the sample surface [21]. Mathematical treatment of the SEM data has shown that the average pore diameter is $42 \pm 4 \mathrm{~nm}$ and the distance between their centres is $83 \pm 2 v \mu$ [21].

To fill AAO pore $J$-aggregates with different structures has been chosen: spherical BIC $J$-aggregates [22] and thread-like PIC $J$-aggregates [23]. Recently it was shown that BIC $J$-aggregates possess unique thermal stability due to their spherical structure with an average diameter about $20 \mathrm{~nm}$ [22]. Contrary, PIC $J$-aggregates which are among the most studied types of $J$-aggregates [4-8] look like threads with a length up to $10 \mu \mathrm{m}$ and a diameter of $2.3 \mathrm{~nm}$ [23].

\section{Experimental}

PIC (1,1'-diethyl-2,2'-cyanine iodide, pseudoisocyanine) dye was purchased from Sigma Aldrich (USA) and used as-received. To prepare PIC $J$-aggregates the dye was dissolved in aqueous solution of $\mathrm{NaCl}$ $(0.2 \mathrm{M})$. As result intense $J$-band in absorption spectrum $\left(\lambda_{\max }=572.5 \mathrm{~nm}\right)$ was observed [23]. BIC or TTBC anionic dye (1,1'-diethyl-3,3'-bis-(3-sulfopropyl)-5,5',6,6' tetrachlorobenzimidazolocarbocyanine) was synthesized by Dr. I.A.Borovoy (Institute for Scintillation Materials NAS of Ukraine) with purity controlled by NMR and thin layer chromatography. To prepare BIC $J$-aggregates the dye was dissolved in aqueous solution $\left(C=10^{-3} \mathrm{M}\right)$. As result intense $J$ band in absorption spectrum $\left(\lambda_{a b s}=\right.$ $594 \mathrm{~nm})$ and in luminescence spectrum $\left(\lambda_{\text {lum }}\right.$ $=609 \mathrm{~nm}$ ) was appeared [22]. Preparation details of porous anodic aluminium oxide templates were described in [21]. To put $J$-aggregates into AAO matrix it was immersed in the $J$-aggregates aqueous solutions for at least $24 \mathrm{~h}$ that leads to intense uniform matrix coloration. Then the surface of composite obtained was washed with alcohol to remove the dye excess.

Absorption spectra were registered using microspectrometer USB4000 (OceanOptics, USA) supplied with an incandescent lamp. Luminescence and luminescence excitation spectra were recorded using fluorescence spectrometer Lumina (Thermo Scientific, USA). Measurements have been done using a solid sample holder. Luminescent images and spectra were obtained using luminescence microscope MIKMED-2 var.11 (LOMO, Russia) equipped with 5 Mpixels microscope digital camera DCM510 (Oplenic Optronics, USA) and fiber-optic adapter for microspectrometer USB4000. Excitation was filtered by 450-480 $\mathrm{nm}$ band filter and luminescence was collected in the $520-700 \mathrm{~nm}$ spectral range. The equipment used allows collecting luminescent spectra from the spots with a diameter less than $50 \mu \mathrm{m}$. Luminescence decay spectra were registered using FluoTime 200 fluorescence lifetime spectrometer (PicoQuant, Germany) equipped with $531 \mathrm{~nm}$ picosecond pulsed laser diode head. An instrument response function (IRF) width (FWHM) for the whole setup was about 100 ps.

\section{Results and discussion}

After impregnation the AAO matrices by BIC and PIC $J$-aggregates the matrices were coloured and revealed correspondent $J$-aggregates spectra (Fig. 1). In comparison with the aqueous solution in nanoporous films significant $J$-aggregate absorption band ( $J$-band) broadening was observed: for BIC $J$-aggregates from $\Delta v_{J}^{\text {solution }}=645 \mathrm{~cm}^{-1}$ in the solution [22] to $\Delta v_{J}$ film $=785 \mathrm{~cm}^{-1}$ in the film (Fig. 1a) and for PIC dye from $\Delta v_{J}$ solution $=$ $150 \mathrm{~cm}^{-1}$ [23] in the solution to $\Delta v_{J}$ film $=$ $450 \mathrm{~cm}^{-1}$ in the film (Fig. 1b). In the case of BIC $J$-aggregates the broadening is a quite 

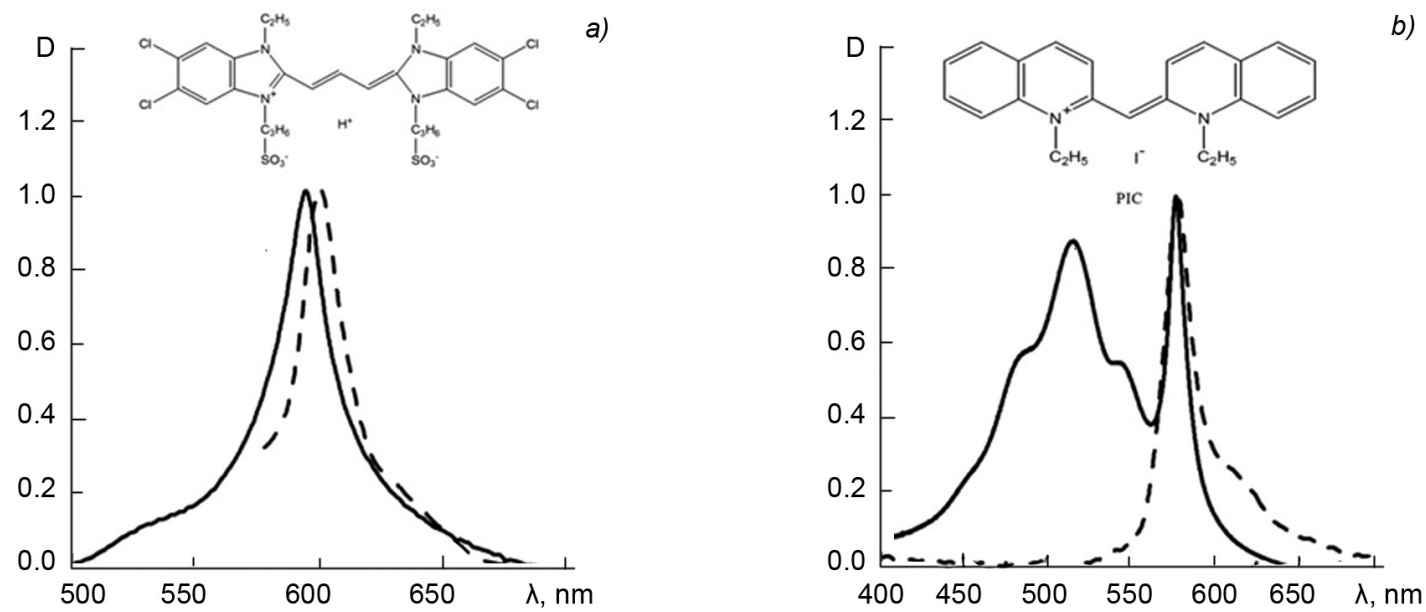

Fig. 1. Absorption and luminescence $\left(\lambda_{\text {exc }}=530 \mathrm{~nm}\right)$ spectra of a) BIC $J$-aggregates and b) PIC $J$-aggregates in the AAO matrix. On inset - chemical structure of the corresponding dyes.

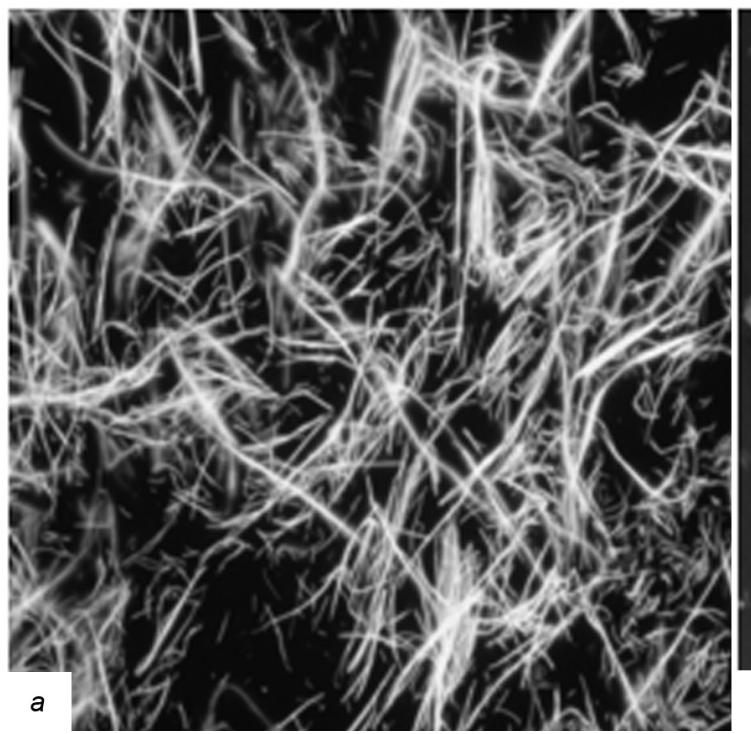

Fig. 2. Fluorescent images of PIC $J$-aggregates in

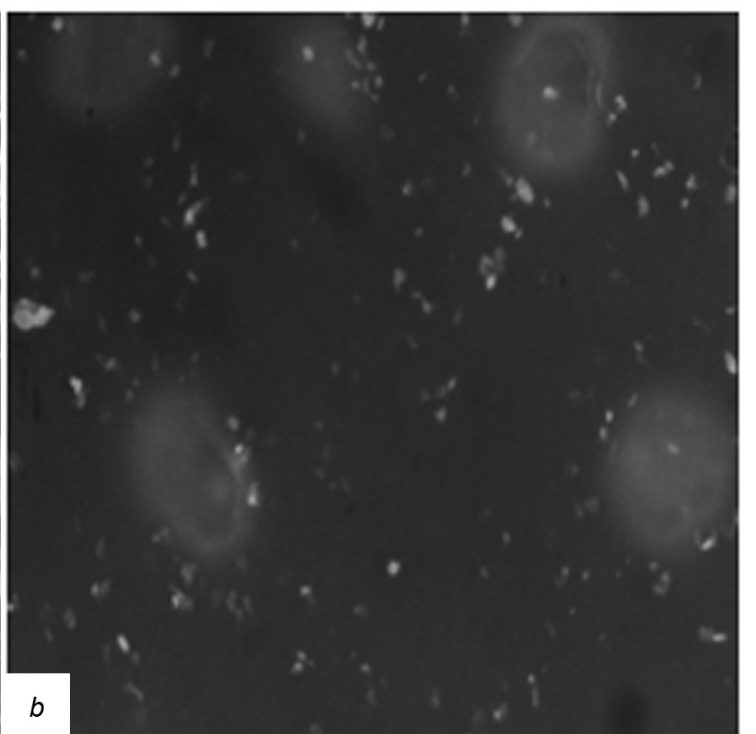

a) the aqueous solution and b) the AAO matrix. small (1.2 times) and could be associated with static disorder increasing [24]. Such phenomenon is often observed for $J$-aggregate formation in solid matrices and could be explained by surrounding effect on the molecular chains [4, 8, 11, 12]. Contrary, in the case of PIC $J$-aggregates formed in the AAO pores threefold increasing of the $J$-band was observed. Such large broadening couldn't be explained by the static disorder contribution only. One of possible reasons is PIC J-aggregates structure changing due to spatial confinement by the pores. Indeed, porphyrin $J$-aggregates formed in the AAO matrix revealed nanotube structure with parameters corresponding to the AAO pores geometry [20]. As PIC $J$-aggregates threads much bigger compared with the AAO pores they should to be reorganized while embedded into the matrix. Despite, as BIC $J$-aggregates are small enough to enter into the pores they structure remains unchanged.

Changes in the PIC $J$-aggregates structure could be confirmed by images taken using a fluorescent microscope. While in aqueous solutions thread-like structures obviously seen (Fig. 2a) in the AAO films $J$ aggregates look like separate bright spots of smaller size, i.e. aggregates' size is strongly decreased (Fig. 2b). Of course, due to the diffraction limit of optical resolution their physical size cann't be determined exactly [1]. Besides, using fluorescent microscopy PIC $J$-aggregates were detected throughout all the depth of the cleaved AOA film. In contrast to the PIC $J$-aggregates, $J$-aggre- 

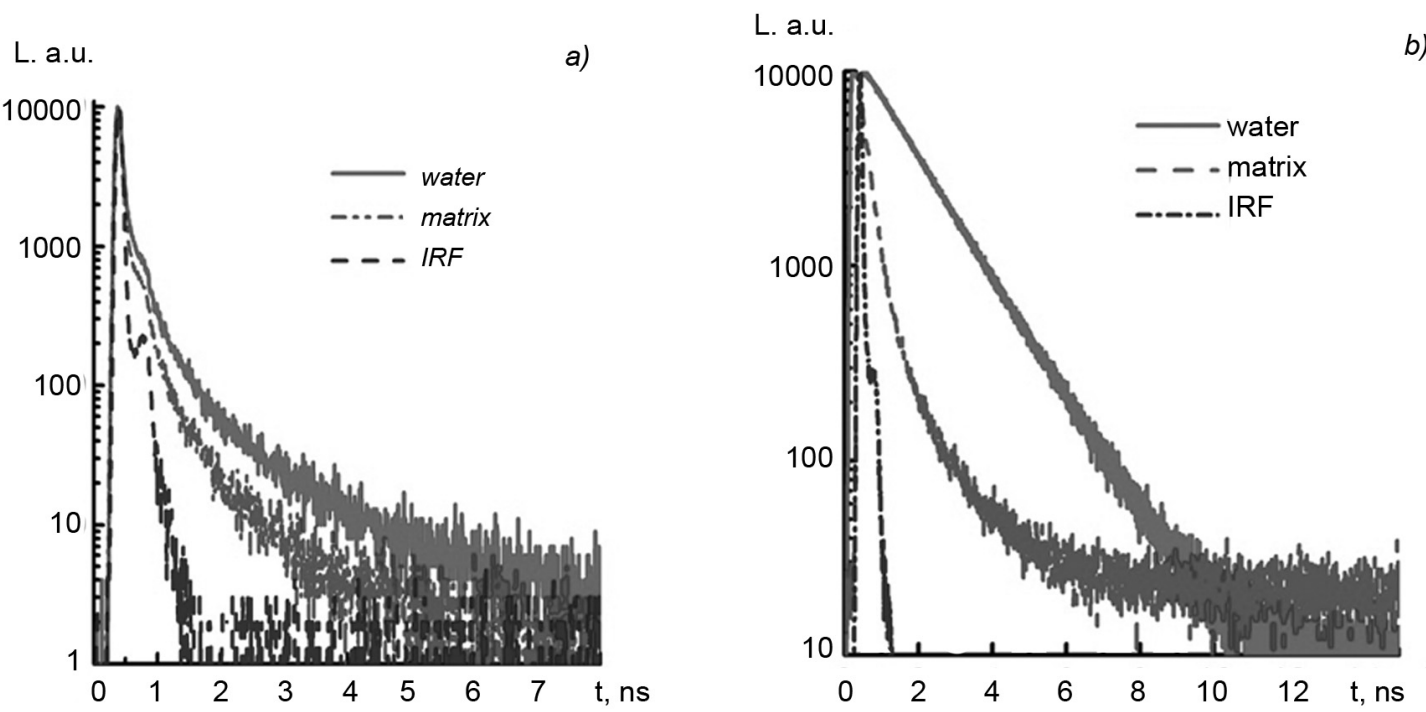

Fig. 3. Luminescence decay curves for a) BIC $J$-aggregates $\left(\lambda_{r e g}=600 \mathrm{~nm}\right)$ and b) PIC $J$-aggregates $\left(\lambda_{\text {exc }}=580 \mathrm{~nm}\right)$ in different media.

gates of BIC apparently preserve their structure during formation in AAO films. Their fluorescent images look similar both in the solution and in the film (not shown) and correspond to the PIC $J$-aggregates in the AAO matrix images (Fig. 2a).

To confirm these observations luminescence decay curves of $J$-aggregates in the aqueous solution and in the AAO films were recorded (Fig. 3). For BIC $J$-aggregates in aqueous solution the decay curve appears to be not single-exponential and can be approximated by two exponential decays with $\tau_{1} \sim 232$ ps (84\%, amplitude weighted) and $\tau_{2} \sim 76$ ps (16\%, amplitude weighted) and

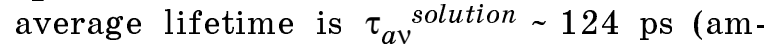
plitude weighted) [15]. In AAO films, the curves of luminescence decay also can be approximated by two exponential curves, with average decay time reduced to $\tau_{a v}$ film 75 ps (Fig. 3a). Moreover, in both cases, contribution of luminescence of monomers is significant. Lifetime decrease could be associated with static disorder increasing caused by the spatial restriction in the AAO pores [4-8].

In the case of PIC $J$-aggregates in the AAO films a significant deviation from the monoexponential decay law which is characteristic to the luminescence decay in aqueous solution [25] was observed (Fig. 3b). Furthermore significant reduction of lifetime to $\tau_{a v}{ }^{\text {film }} \approx 0.6 \mathrm{~ns}$ as compared with that in aqueous solution $\left(\tau_{a v}^{\text {solution }} \approx 1.4 \mathrm{~ns}\right)$ [17] was observed. These changes have con- firmed the hypothesis that the exciton properties of PIC $J$-aggregates at the formation in the nanoporous AAO are result of not only static disorder increase but also the structure changing.

\section{Conclusions}

$J$-aggregates formation in the nanoporous anodic aluminium oxide films has been studied using steady-state and time-resolved spectroscopy. Spherical BIC $J$-aggregates penetrate into the pores with small changing their spectral properties and structure caused by static disorder increasing. PIC $J$-aggregates formation in the AAO pores results in their structure change leading to significant spectral properties transformation.

Acknowledgments. Authors are very appreciative to Prof.Yu.V.Malyukin (Institute for Scintillation Materials of NAS of Ukraine) for fruitful discussion of the results obtained.

\section{References}

1. Nano-Optics and Near-Field Optical Microscopy, ed. by A.Zayats, D.Richards, Artech House, Boston (2009).

2. Handbook of Nanoscale Optics and Electronics, ed. by G.P.Wiederrecht, Elsevier B.V., Amsterdam (2010).

3. Macro to Nano Spectroscopy, ed. by J.Uddin, InTech, Rijeka (2012).

4. D.Mobius, Adv. Matter., 7, 437 (1995).

5. .J-aggregates, ed by T.Kobayashi, World Scientific Publishing, Singapore (1996).

6. B.I.Shapiro, Russ.Chem.Rev., 75, 433 (2006). 
7. J.Knoester, V.M.Agranovich, in: Electronic Excitations in Organic Based Nanostructures. Thin Films and Nanostructures, ed. by V.M.Agranovich and G.F.Bassani, Elsevier, Amsterdam, Oxford (2003).

8. F.Wurthner, T.E.Kaiser, Ch.R.Saha-Muller, Angew Chem. Int. Ed., 50, 3376 (2011).

9. R.V.Markov, A.I.Plekhanov, S.G.Rautian et al., Opt. and Spectr., 85, 588 (1998).

10. V.V.Shelkovnikov, A.I.Plekhanov, N.A. Orlova, Nanotechnol. Russia, 3, 521 (2008).

11. A.V.Sorokin, B.A.Gnap, I.I.Fylymonova, S.L.Yefimova, Functional Materials, 19, 70 (2012).

12. A.V.Sorokin, I.I.Fylymonova, S.L.Yefimova, Yu.V.Malyukin, Opt.Mater., 32, 2091 (2012).

13. G.Q.Lu, X.S.Zhao, Nanoporous Materials: Science and Engineering, Imperial College Press, London (2004).

14. Y.P.Dan, Y.Y.Cao, T.E.Mallouk et al., Sens. Actuators. B, 125, 55 (2007).

15. S.X. Xiong, Q.Wang, H.S.Xia, Mater.Res. Bull., 39, 1569 (2004).
16. Y.Fujiwara, Y.Amao, Sens. and Actuators, 89 , 58 (2003).

17. M.Farooq, Z.H.Lee, Renew.Energy., 28, 1421 (2003).

18. Z.B.Fang, Y.Y.Wang, X.P.Peng et al., Mater. Lett., 57, 4187 (2003).

19. G.A.Wurtz, P.R.Evans, W.Hendren et al., Nano Lett., 7, 1297 (2007).

20. Q.Liu, J.Zhu, T.Sun, H.Zhou et al., RSC Adv., 3, 2765 (2013)

21. A.V. Voloshko, V.V.Danilina, P.V.Mateychenko, I.I.Bespalova, Functional Materials, 19, 44 (2012).

22. I.I.Fylymonova, S.L.Yefimova, A.V.Sorokin, Functional Materials, 19, 348 (2012).

23. A.N.Lebedenko, G.Ya.Guralchuk, A.V.Sorokin et al., J.Phys. Chem. B, 110, 17772 (2006).

24. G.Ya.Guralchuk, I.K.Katrunov, R.S.Grynyov et al., J.Phys. Chem. C, 112, 14762 (2008).

25. A.V.Sorokin, I.I.Fylymonova, N.V.Pereverzev, S.L.Yefimova, Functional Materials, 19, 498 (2012). 